\title{
ILUSI OPTIS DALAM DUNIA SENI DAN DESAIN
}

\author{
Jonata Witabora \\ Jurusan Desain Komunikasi Visual, School of Design, BINUS University \\ Jln. K.H. Syahdan No. 9, Palmerah, Jakarta Barat 11480 \\ jowitabora@binus.edu
}

\begin{abstract}
Visual is everything to do with vision. The ability of our brain to interpret visual is what we call visual perception. In the development of art and design, many artists and designers study visual perception and embody it in their works. One part of visual perception which attracts artists and made as the base on their work is optical illusion. This, in turn creates new streams in the world of art and design. Optical illusion is an anomaly in visual perception, a deceiving experience occurs beyond the control of the observer. Article maps out what optical illusions is, and identify a variety of optical illusions and their application in art and design.
\end{abstract}

Keywords: optical illusion, arts, visual

\begin{abstract}
ABSTRAK
Visual adalah segala sesuatu yang berkaitan dengan penglihatan. Kemampuan otak kita untuk memaknai visual tersebut kita sebut persepi atau lebih tepatnya dalam konteks visual kita sebut persepsi visual. Dalam perkembangan dunia seni dan desain, banyak seniman dan desainer mempelajari persepsi visual dan berusaha menuangkannya dalam karya mereka. Salah satu bagian dari persepsi visual yang menarik para seniman dan menjadikannya sebagai basis karya mereka adalah ilusi optis. Hal ini pada akhirnya akan memunculkan aliran-aliran baru dalam dunia seni dan desain. Ilusi optis merupakan anomali dalam persepsi visual, suatu pengalaman tipuan mata yang terjadi di luar kendali sang pengamat. Artikel memetakan ilusi optis dan mengidentifikasi macam-macam ilusi optis serta penerapannya pada karya seni dan desain.
\end{abstract}

Kata kunci: ilusi optik, seni, desain 


\section{PENDAHULUAN}

Seniman dan desainer telah mempelajari, menerapkan dan bereksplorasi dalam menciptakan persepsi visual pada karya-karyanya. Bagaimana bangsa Mesir menggambarkan persepsi visual mereka akan manusia yang dibuat selalu menghadap ke samping namun mata tetap tampak dari depan, Lukisan bangsa Cina dari dinasti Sung, yang menerjemahkan dimensi kedalaman dengan menempatkan objek terjauh di posisi paling atas, dan bangsa Italia yang mempelajari perspektif untuk mencari kesempurnaan dalam menciptakan karya lukisan. Mulai dari menerapkan prinsip yang membuat penerjemahan realitas ke karya mereka mendekati ke kesempurnaan mimicry, hingga penemuan-penemuan fenomena atau anomali visual dan disertai perkembangan ilmu pengetahuan dan teknologi, dunia psikologi serta paham-paham baru yang pada akhirnya menciptakan pemikiran dan pendalaman yang berbeda-beda dalam menghadapi dan bereksplorasi pada persepsi visual, menghasilkan aliran-aliran baru seperti impresionisme, surealisme hingga optical art (op art).

Ilusi Optis sendiri belum menjadi suatu istilah yang awam pada awalnya. Penemuan prinsipprinsip perspektif mengawali perkembangan eksplorasi ilusi optis. Mungkin bukti tertua bahwa ilusi optis menjadi suatu tema dalam berkarya adalah karya Leonardo Da Vinci, yaitu Leonardo Eye's (1485). Gambar tersebut menggunakan teknik yang kita sebut anamorfisme, di mana dalam karya Leonardo Eye's, gambar tersebut baru terlihat seperti gambar mata ketika dilihat dengan sudut tertentu. Teknik tersebut berkembang pada era awal renaissance, dan karya lukis anamorfisme yang paling terkenal adalah karya lukis Hans Holbein the Younger dalam The Ambassadors (1533). Di mana ada penggambaran tengkorak yang merupakan simbol dari vanitas atau memento mori yang dibuat tersembunyi dalam bentuk anamorfisme. Dari situ perkembangan penerapan ilusi optis terus berkembang hingga merambah disiplin seni lain sampai sekarang. Penulisan ini akan membatasi pembahasan karya-karya seni dan desain yang menerapkan ilusi optis sebagai tujuan utama karya tersebut, dengan memperlihatkan prinsip-prinsip apa saja yang digunakan dalam menghasilkan ilusi tersebut. Dengan mempelajari prinsip-prinsip tersebut maka pemahaman ilusi optis akan semakin kaya dan mendalam, dan pada akhirnya membuat pembaca bisa menerapkan prinsip-prinsip tersebut dalam berkarya.

\section{METODE}

Penelitian menggunakan pendekatan studi literatur, yaitu mencari berbagai sumber yang terkait dengan teori persepsi, prinsip dasar seni dan desain dari media cetak maupun media elektronik. Yang kemudian dipelajari dan diseleksi dan dijadikan bahan pendukung penulisan ini. Selain itu, dilakukan observasi karya seni dan desain untuk memperjelas penulisan yang dimaksud.

\section{HASIL DAN PEMBAHASAN}

Ilusi optis terjadi ketika persepsi visual sang pengamat pada suatu objek tidak sama dengan atribut sebenarnya objek tersebut. Bahwa stimuli yang diterima mata, kemudian diproses oleh otak kita menyampaikan informasi yang berbeda dengan kenyataan sebenarnya. Hal ini bisa terjadi karena berbagai hal.

Secara garis besar ada 3 macam ilusi optis, yaitu: (1) literal optical illusion, ilusi optis objek yang terlihat memiliki pencitraan yang berbeda dengan yang sebenarnya; (2) pscyhology optical illusion, ilusi optis yang terjadi ketika mata dan otak diberi stimulasi tertentu (seperti warna, ukuran, posisi) yang berlebihan; dan (3) cognitive optical illusion, ilusi optis yang terjadi akibat hasil dari pengolahan informasi di luar kendali atau bawah sadar. 
Secara kognitif, ilusi optis dapat terbagi-bagi lagi berdasarkan ilusi yang terjadi: (1) ambigous illusions atau figure/ground, ilusi yang terjadi ketika lebih dari satu interpretasi visual muncul dalam waktu yang bersamaan; (2) distorting/geometrical-optical illusions/anamorphosis, ilusi yang terjadi yang bersifat distorsi suatu bentuk akibat penempatan, ukuran,sudut dari elemen geometris pembentuk visual tersebut; (3) paradox illusions, ilusi dari objek yang secara logika tidak masuk akal atau mustahil tapi bisa terlihat benar; dan (4) fictions, ilusi yang terjadi ketika kita melihat sebuah figur walaupun sebenarnya pada kenyataannya tidak ada.

Dalam memahami ilusi optis secara kognitif, sebaiknya kita juga memahami prinsip-prinsip gestalt yang menjelaskan bagaimana kita sebenarnya mempersepsikan suatu objek. Pragnanz/Law of good figure, bahwa kita menangkap visual dengan mencintrakannya sebagai struktur yang sesederhana mungkin. Similarity, bahwa objek-objek yang memiliki persamaan karakter akan terlihat sebagai satu kesatuan. Continuation, bahwa persepsi garis lurus ataupun lengkung akan tetap terlihat sebagai satu kesatuan objek, walaupun garis tersebut saling menimpa satu sama lain. Proximity atau nearness, bahwa objek-objek yang diletakkan berdekatan akan terlihat sebagai satu kesatuan. Common fate, bahwa objek-objek yang bergerak dalam arah yang sama akan terlihat sebagai satu kesatuan. Meaningfulness atau familiarity, bahwa objek-objek yang lazim akan lebih mudah dikenali walaupun tidak terlihat secara utuh karena kita mengenali maknanya di atas bentuknya. Pemahaman prinsipprinsip tersebut, ditambah dengan prinsip visual segregation/figure ground, serta pemahaman akan ukuran, pergerakan, dimensi atau kedalaman merupakan kunci dalam penciptaan suatu ilusi optis.

Setelah mengenal prinsip-prinsip di atas, akan lebih mudah lagi bagi kita untuk memahami cara kerja ilusi optis dengan menggunakan contoh-contoh karya yang sudah ada dan berusaha menguraikan visual puzzle dari karya tersebut menggunakan prinsip-prinsip yang sudah kita ketahui. Namun, sebelum itu ada baiknya juga kita mengenal sekilas beberapa seniman, desainer yang konsisten menggunakan prinsip ilusi optis, tidak hanya sebagai salah satu prinsip dalam berkarya tapi menjadi tema tunggal dalam karya-karya mereka.

M.C Escher (1898-1972), seorang graphic artist dari Belanda, karya-karyanya kebanyakan merupakan karya cukil, litografi dan mezzotint. Karya-karyanya kuat menggunakan prinsip figure/ground yang digabungkan dengan metode tesselations. Tesselations secara pemahaman sederhana bisa kita samakan dengan pengertian tiling. Tesselation adalah proses pembuatan suatu bidang dengan menggunakan pengulangan bentuk geometris yang sama tanpa saling menimpa atau meniggalkan ruang sisa. Jadi setiap sisi dari bentuk geometris tersebut harus saling bersentuhan dengan yang lainnya secara persis. Selain itu, karya-karya M. C Escher juga terkenal dengan ide infinity (tak berkehabisan) dan objek yang mustahil.

Shigeo Fukuda (1932-2009), seorang desainer dari Jepang. Ia digambarkan sebagai ”Japan consummate visual communicator", menandakan keahliannya dalam menghasilkan karya. Dengan ciri khas desain Jepang yang kuat, yaitu kesederhanaan (simplicity) dalam karyanya serta permainan ilusi dalam mengomunikasikan visual yang dibuatnya, membuat karya-karyanya memiliki ciri khas tersendiri dengan bentuk-bentuk berupa logo, poster, hingga sculpture. Mulai dari pendekatan ilusi dari segi psikologis sampai fisikal seperti impossible objek dilakoninya dalam ekspolorasi ilusi optis. Dan masih banyak lagi artis lain yang masih berkarya sampai sekarang, seperti István Orosz dan Akiyoshi Kitaoka (terkenal akan karya "rotating snake”-nya).

\section{Literal Optical Illusion}

Literal Optical Illusion adalah ilusi yang secara nyata dalam kondisi tertentu terlihat berbeda dari yang sebenarnya. Ilusi ini terjadi dengan cara memanipulasi otak kita. Otak kita telah berevolusi untuk beradaptasi di dunia ini. Contohnya, bagaimana kita menginterpretasikan bayangan untuk menentukan dimensi, kedalaman, dan gerak. Otak kita juga memiliki sistematis pengenalan, sehingga 
kita mudah dan secara otomatis mengenali objek-objek yang sudah kita kenal dengan hanya dengan melihat key feature objek tersebut.

Mengenal prinsip ini, kita bisa dengan mudah memanipulasi suatu gambar sesuai dengan yang kita inginkan. Seperti spesial efek klasik di film-film jaman dahulu, di mana untuk ilusi seseorang memanjat tebing dilakukan dengan posisi horizontal kameranya yang diposisikan vertikal, namun tayangan dilakukan horizontal sehingga terlihat seperti benar-benar sedang memanjat. Atau, dengan sengaja menciptakan adegan yang tidak mungkin, seperti foto profil Shigeo Fukuda di bawah ini.

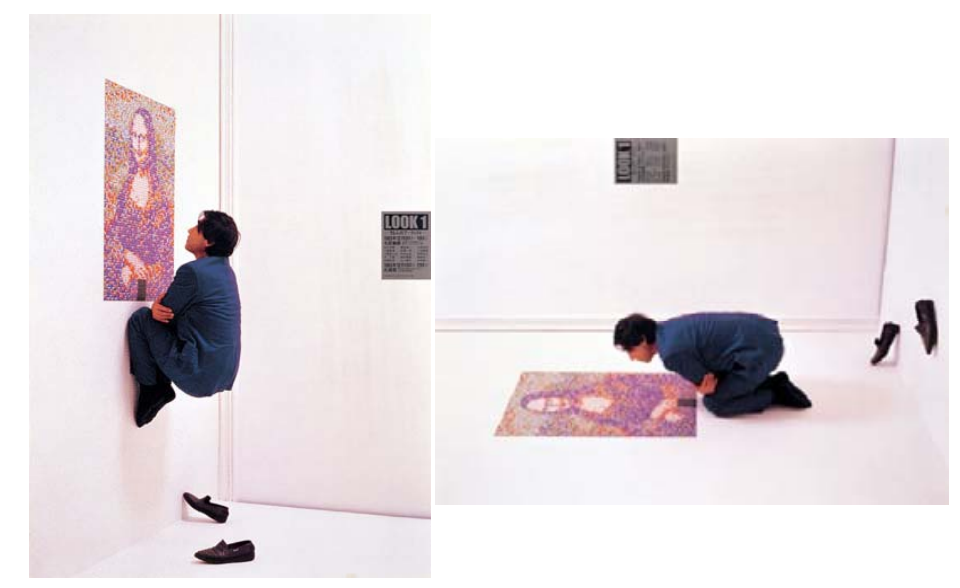

Gambar 1 Foto profil Shigeo Fukuda

Foto pada Gambar 1 (sebelah kiri) memperlihatkan keganjilan gravitasi; sesuatu yang mustahil, tetapi menjadi sesuatu yang bisa dipercaya. Sementara itu, Gambar 1 (sebelah kanan) dengan orientasi sesungguhnya. Mata kita tertipu dengan penempatan sepatu dan orientasi dari selebaran "Look" yang ditempel.

Kemampuan otak kita untuk mengenal bentuk wajah sungguh mengagumkan sehingga sering kita begitu mudah melihat suatu objek menyerupai suatu wajah. Hal ini juga dinyatakan dalam contoh Gambar 2.

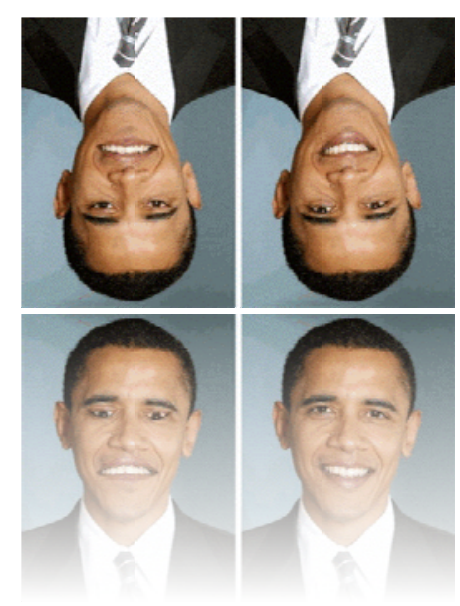

Gambar 2 Contoh ilusi objek 
Foto ini memperlihatkan bahwa kedua gambar Presiden Barack Obama secara sekilas tidak terlihat keanehan, walaupun sebenarnya gambar sebelah kiri memiliki keganjilan di mana mata dan mulut Presiden Barack Obama dibuat terbalik. Namun karena diposisikan terbalik, otak kita berusaha mengenali wajah tersebut dan secara otomatis memperbaiki persepsi tersebut tanpa kita sadari.

Contoh lain Shadowsculpture karya shigeo Fukuda adalah lunch with a helmet on (1987). Pada karya tersebut dengan memercayai gambaran bayangan dari sebuah motor. Otak kita karena telah mengenal bentuk motor, otomatis akan beranggapan bahwa objek yang menciptakan bayangan motor tersebut pastilah sebuah motor. Akan tetapi, pada kenyataannya tidak demikian. Objek tersebut bukanlah motor, melainkan kumpulan sendok dan garpu yang disusun sedemikian rupa menjadi satu kesatuan bentuk yang jauh berbeda bentuk dari sebuah motor. Kunci dari sculpture ini adalah konsistensi sudut penyinaran dan penempatan yang cermat akan elemen-elemen yang memberi bentuk pada bayangan masing-masing elemen.

\section{Psychology Optical Illusion}

Ilusi Optis secara psikologis adalah segala ilusi optis yang dihasilkan karena rangsangan visual berupa terang/gelap, warna, ukuran, komposisi suatu objek dengan intensivitas yang kuat dan berulangulang pada kondisi tertentu, yang menghasilkan ketidakseimbangan pengiriman sinyal-sinyal neuron sehingga menghasilkan informasi yang berbeda antara yang terlihat mata dan ditangkap otak. Contoh yang paling dikenal dari ilusi optis secara psikologis adalah after effect.

After Effect terjadi karena alat peka visual (visual sensory) kita dari waktu ke waktu selalu beradaptasi dalam menerima rangsangan visual akibat berusaha menerima rangsangan yang saling berlawanan dalam waktu yang bersamaan dan terus menerus. Akibat dari rangsangan tersebut maka kemampuan fokus mata (fixational eye movements) kita akan suatu objek akan hilang karena mata kita berusaha fokus untuk dua hal yang terus-menerus berubah atau bergerak. Maka persepsi visual yang terjadi seakan objek tersebut perlahan-lahan hilang dan muncul atau akan saling berganti-ganti antara satu objek dengan objek yang lainnya.

After Effect dalam visual dapat dibagi menjadi dua yaitu after image dan motion after image. Penelitian terhadap after effect ini telah banyak dilakukan. Dengan penelitian menggunakan magnetoencephalography (MEG) diketahuilah bagaimana after image dan motion after image terjadi. Dari penelitian tersebut, maka akhirnya dihasilkan bukti visual-visual yang menarik, dan akhirnya berkembang dan bisa kita anggap suatu karya seni tersendiri di mana dibutuhkan pengetahuan akan science dan kepekaan visual untuk menghasilkannya.

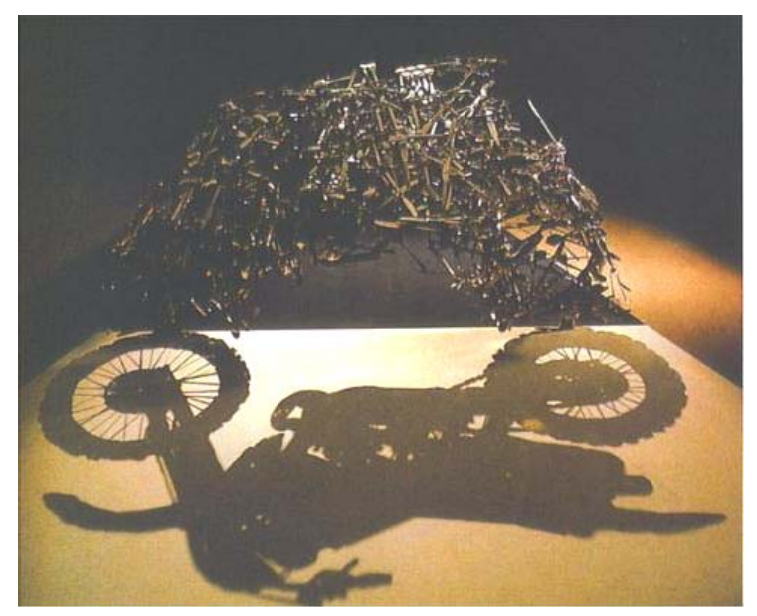

Gambar 3 Foto Lunch with a Helmet, Shigeo Fukuda (1987) 


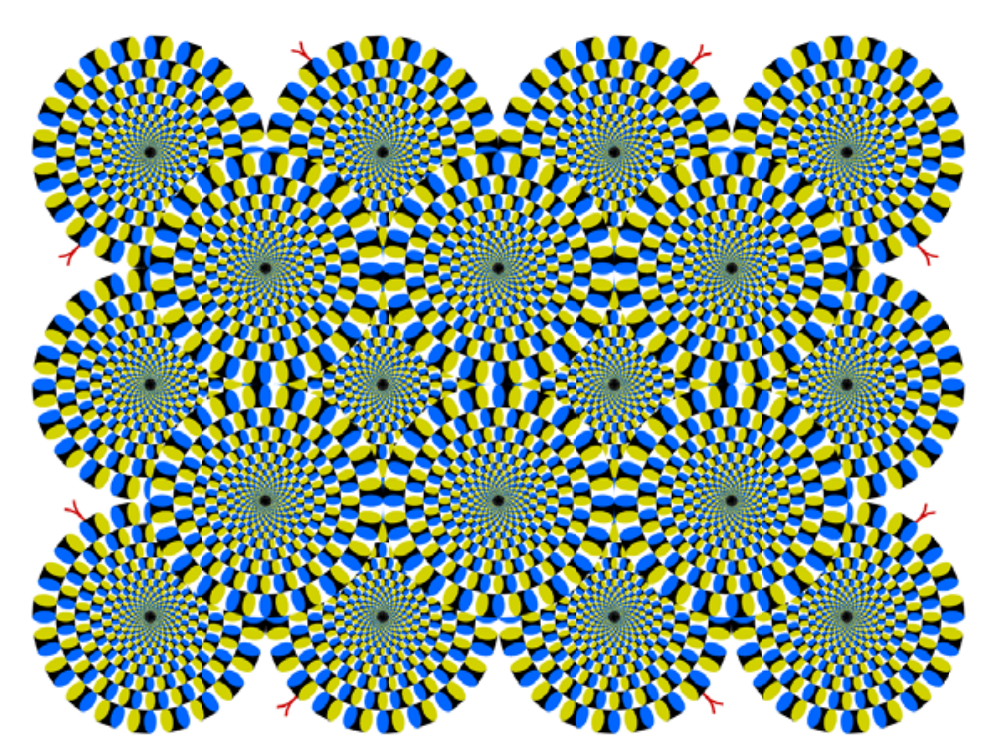

Gambar 4 Rotating snake karya Akiyoshi Kitaoka

Akiyoshi Kitaoka adalah seorang profesor psikologi dari universitas Ritsumeikan, Kyoto yang mempelajari mengenai persepsi visual, ilusi optis yang banyak menghasilkan karya visual optis.Tanpa kita bisa cegah mata kita akan menerima persepsi gerak dari lingkaran-lingkaran tersebut, seakan-akan seperti ular. Hal ini seperti disebutkan oleh Profesor Akiyoshi, adalah akibat komposisi warna dengan tone gelap—agak gelap—putih—kurang gelap. Ditambah dengan kontras warna kuning dan biru sehingga menyebabkan gerak yang terus-menerus.

Ilusi optis secara psikologi bisa juga dijelaskan dengan kemampuan lateral inhibition mata kita (dalam bidang neurobiology), adalah kemampuan kapasitas aktif neuron untuk mengurangi keaktifannya berhubungan dengan kapasitas aktif neuron-neuron di sebelahnya. Menghasilkan stimuli yang terlokalisasi. Hal ini bisa dilihat dari ilusi warna yang terlihat berbeda namun sebenarnya memiliki warna yang sama, seperti terlihat pada Gambar 5.

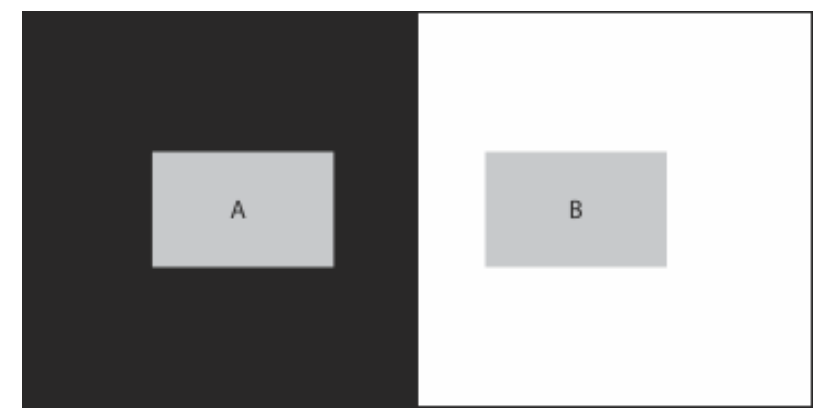

Gambar 5 Ilusi optis secara psikologi

Kotak abu-abu A dan B sebenarnya memiliki warna yang sama, namun terlihat berbeda karena relasi atau hubungannya dengan warna latar belakangnya. Kotak abu-abu B dengan latar belakang putih kan terlihat menjadi lebih gelap sedangkan jika diletakkan dasar yang gelap maka kotak abu-abu itu akan terlihat lebih terang. 
Ilusi hermann grid dan ilusi scintillating grid memperlihatkan prinsip yang sama, dengan visual yang lebih kompleks. Ilusi Hermann Grid dilaporkan oleh Ludimar Hermann pada tahun 1870. Ilusi ini berupa penampakan lingkaran abu-abu pada setiap persimpangan grid ketika mata melihat secara keseluruhan, namun ketika kita fokus pada titik persimpangan itu maka lingkaran abu-abu tersebut tidak muncul. Ilusi ini kemudian dipertegas lagi dengan kemunculan ilusi scintillating grid yang ditemukan oleh E. Lingelbach tahun 1994.

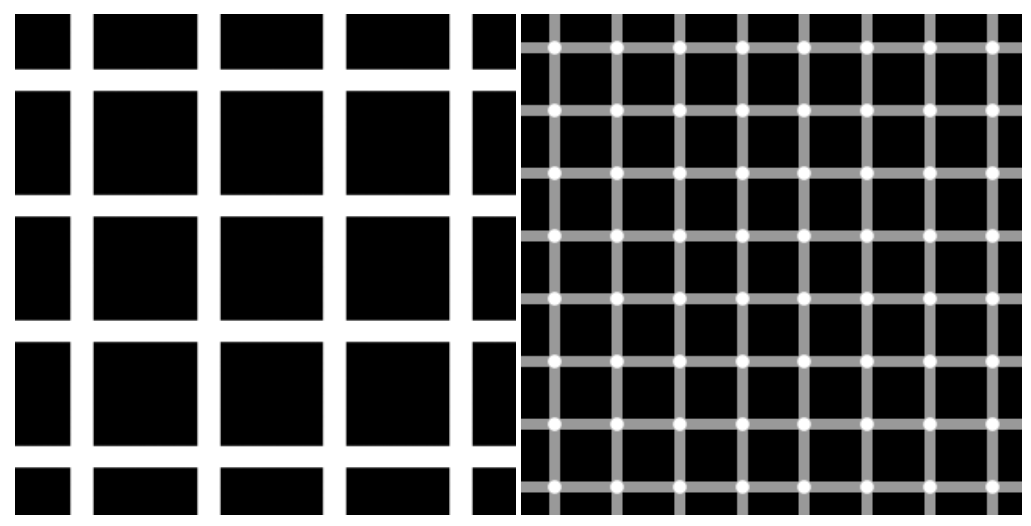

Gambar 6 (a) Hermann Grid; (b) Scintillating Grid

\section{Cognitive Optical Illusion}

Merupakan teori ilusi optis berdasarkan pengolahan informasi berdasarkan adanya keterlibatan bawah sadar kita. Ilusi optis ini dapat dibagi-bagi dalam ambiguous illusion. Ambigous Illusion merupakan ilusi optis yang terjadi karena adanya pemaknaan ganda atau lebih dari suatu objek yang terjadi secara spontan. Contoh paling awal dari ilusi ini adalah Necker Cube, merupakan karya Louis Albert Necker tahun 1832.

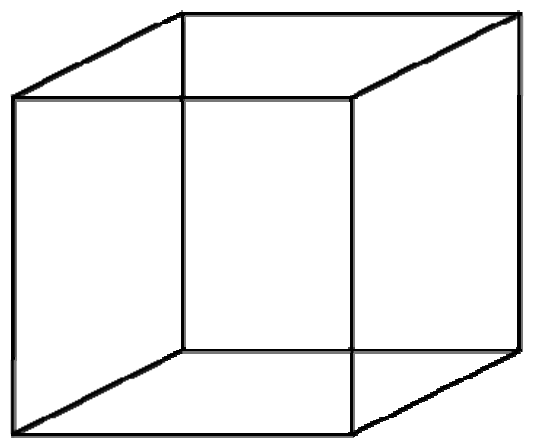

Gambar 7 Necker cube

Pada Necker Cube, kita bisa melihat kubus dengan dua orientasi yang berbeda, kita bisa melihatnya sebagai kubus dengan posisi perspektif di bawah garis horizontal, atau di atas garis horizontal. Dengan kata lain, kita menentukan bujurs angkar mana yang merupakan sisi depan, mana yang merupakan sisi belakang.

Ambigous Illusion juga bisa tercipta ketika dua objek dengan ciri yang hampir sama disatukan dalam satu gambar, sehingga membingungkan mata kita. Hal ini nantinya berkembang menjadi lebih luas dengan meminjam salah satu prinsip gestalt, yaitu prinsip figure/ground. 


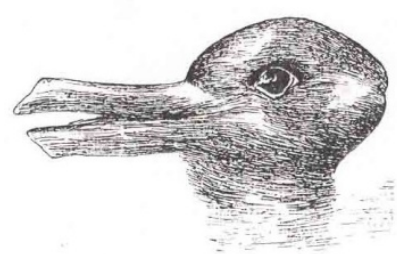

Gambar 8 Contoh prinsip figure/ground

Gambar 8 memperlihatkan ambiguitas antara gambar kelinci atau bebek. Bagaimana seseorang menangkap gambar tertentu dibanding gambar yang lainnya dipengaruhi oleh latar belakang dan stimulasi sebelumnya. Sebagai contoh, seseorang yang didengarkan cerita tentang "bebek si buruk rupa” sebelum diperlihatkan Gambar 8, kemudian diperlihatkan gambar tersebut akan lebih menangkap gambar bebek dibanding kelici. Prinsip figure/ground menyatakan bahwa kita mengenali suatu objek tanpa memisahkan objek tersebut dengan latar belakangnya. Bahwa kontur atau garis luar pembentuk objek tersebut terbentuk karena adanya objek lain. Hal ini diperlihatkan oleh Edgar Rubin pada tahun 1915 dengan karya Rubin’s Vase.

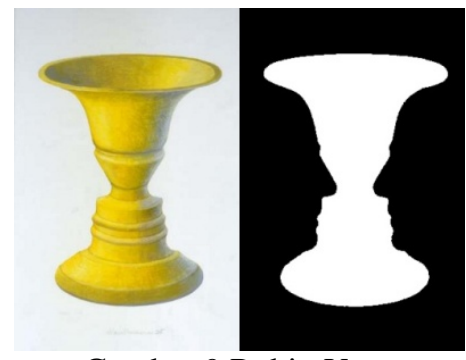

Gambar 9 Rubin Vase

Rubin Vase memperlihatkan dua objek, gambar vas/cawan dan dua profil manusia di sisisisinya. Prinsip figure/ground ini juga yang menginspirasikan M.C Escher, Shigeo Fukuda dan lainlain dalam berkarya. Dalam karya-karya figure/ground M.C Escher kita bisa lihat keahlian Escher dalam menggabungkan ilmu matematika dalam penciptaan visual. Dengan penerapan sistem tiling dengan bentuk modul yang saling mengunci (interlocking) menciptakan visual dengan figure dan ground yang sama-sama memiliki makna visual.

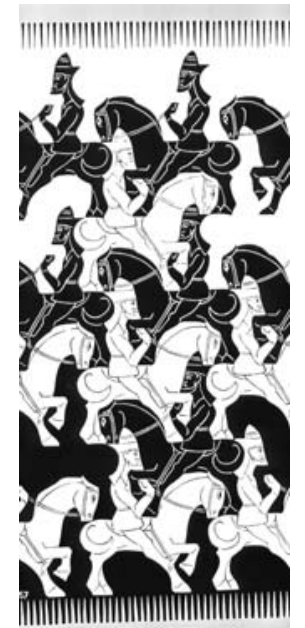

Gambar 10 “The Riders” M.C Escher 
Gambar ini memperlihatkan bagaimana penggambaran penunggang kuda bisa diraih dari postive space (figure) yang berwarna hitam dan negative space (ground) yang berwarna putih, atau sebaliknya.

Prinsip ambigous illusion sebenarnya sudah dilakukan oleh seniman jauh sebelum prinsip ini diperkenalkan. Sebagai contoh karya seniman Arcimboldo, dengan judul Water (1566) yang memperlihatkan potrait manusia dari samping dibentuk oleh komposisi objek sekumpulan binatang laut. Prinsip ini juga menginspirasi seniman seperti Salvador Dali dalam berkarya.

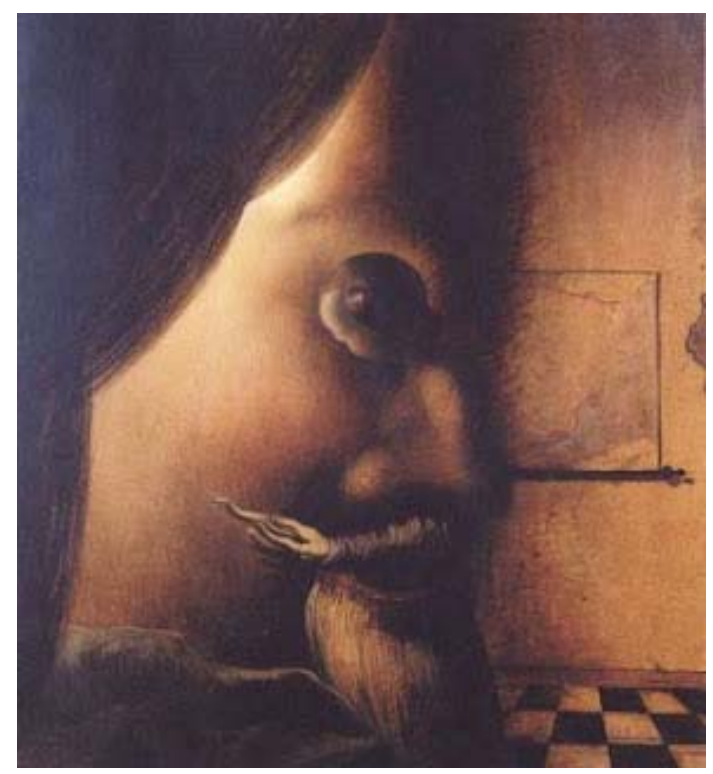

Gambar 11 The Image Disappears oleh Salvador Dali

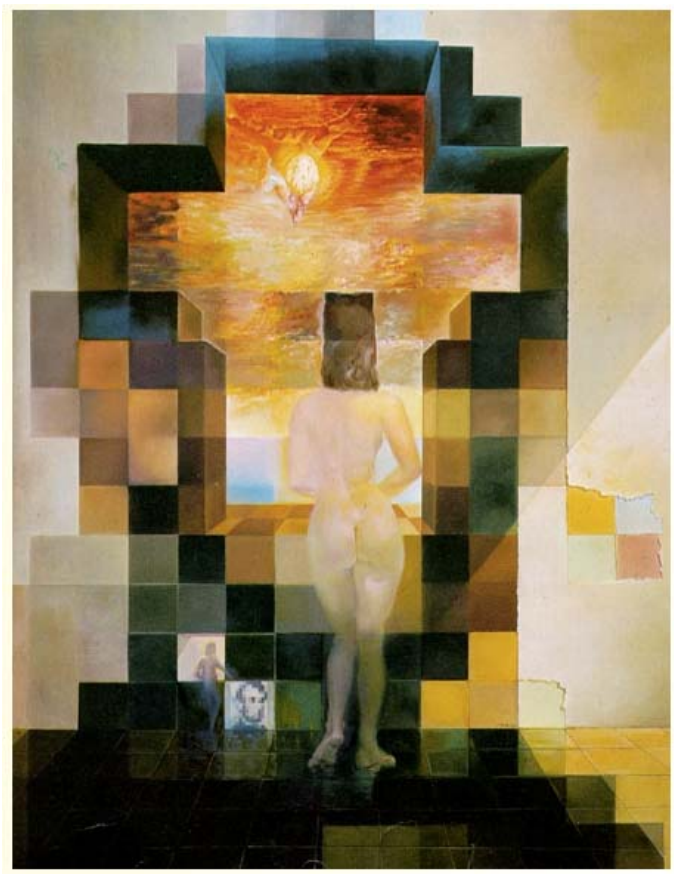

Gambar 12 Gala contemplating the Mediterranean sea karya Salvador Dali. 
Pada “The Image Disappears” (1938), Salvador Dali (Gambar 11) memperlihatkan dua objek antara gambar muka seorang pria dan sosok seorang wanita. Dalam "Gala contemplating the mediterranean sea” (1976), Salvador Dali (Gambar 12) memperlihatkan sosok wanita di jendela menghadap laut Mediterania. Dalam lukisan ini juga terdapat puzzle visual yaitu gambar Abraham Lincoln. Dalam lukisan ini Dali menerapkan prisip pixel dalam menciptakan gambar Abraham Lincoln sehingga sosok Abraham Lincoln hanya muncul jika dilihat dari kejauhan, atau dengan memburamkan (membuat tidak fokus) mata kita saat melihat lukisan tersebut. Sebagai tambahan petunjuk ilusi tersebut, Dali menggambarkan versi kecilnya di salah satu pixel dekat kaki sang wanita.

\section{Distorting/Geometrical-Optical Illusions/Anamorphosis}

Merupakan Distorsi dalam bentuk-bentuk geometris 2D. Ilusi optis ini mudah ditemukan dalam bentuk distorsi kedalaman, jarak, atau ukuran. Ilusi ini dijelaskan dalam penelitian-penelitian ilusi optis seperti pada café wall illusion, ditemukan pada tahun 1973 oleh Richard Gregory, yang memperlihatkan distorsi sudut pada garis pararel ketika antara garis pararel tersebut terdapat kotak hitam putih yang disusun sedemikian rupa, sehingga garis-garis pararel tersebut terlihat menjadi tidak pararel lagi. Ilusi Muller-Lyer yang menyatakan ukuran suatu garis yang sama akan terlihat berbeda panjangnya ketika di ujung-ujung garis tersebut diberikan arah panah yang berbeda. Ilusi vertikalhorizontal, menjelaskan bahwa mata kita akan cenderung menafsirkan garis vertikal lebih panjang dibandingkan dengan garis horizontal walaupun kenyataanya kedua garis tersebut memiliki ukuran panjang yang sama, hal ini bisa dilihat dari percobaan Roger Shepard pada gambar dua meja vertikal dan horizontal yang sama ukuran tapi terlihat jauh berbeda. Ilusi ponzo yang menjelaskan bahwa kita menentukan ukuran suatu objek berdasarkan lingkungan sekitarnya, sehingga objek dengan ukuran sama jika diletakkan lebih jauh dengan latar belakang yang memperlihatkan garis perspektif (garis menuju titik hilang), seperti lorong, rel kereta dan lain-lain bisa terlihat lebih besar atau panjang.

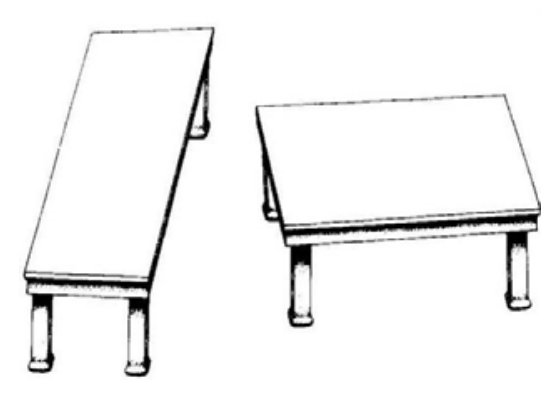

Gambar 13 Turning the Table karya Roger Shepard

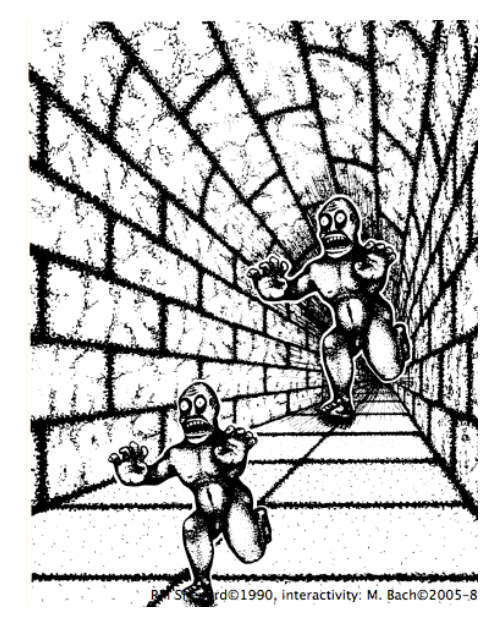

Gambar 14 Terror sub Terra karya Roger Shepard

“Turning the Tabel” karya Roger Shepard (Gambar 13) merupakan kedua gambar meja di atas memiliki ukuran yang sama tapi terlihat jauh berbeda karena persepsi kita akan garis vertikal dan horizontal. "Terror Sub Terra” karya Roger Shepard (Gambar 14) merupakan kedua gambar monster yang memiliki ukuran yang sama tapi karena persepsikita akan objek berdasarkan lingkungannya maka monster di belakang terlihat lebih besar, relatif dengan latar belakangnya. 
Distorsi dalam persepsi terhadap kedalaman terjadi akibat hilangnya atau mengganti petunjuk akan kedalaman tersebut. Dalam distorsi ini dapat kita bagi-bagi lagi berdasarkan tekniknya. Anamorfisme adalah distorsi perspektif, di mana untuk melihat perspektif sesungguhnya hanya bisa dilakukan melalui sudut tertentu. Karya seni abad 17 yang paling terkenal menggunakan prinsip ini adalah karya Andrea Pozzo, yaitu lukisan langit-langit gerja St. Ignazio. Ada pula anamorfisme yang untuk melihat karya tersebut diperlukan alat khusus, seperti silinder yang ditempatkan di posisi yang telah ditentukan dalam karya tersebut, sehingga gambar dengan perspektif yang benar akan muncul pada dinding silinder tersebut. Contohnya, Column karya Istvan Orosz. Pada jaman modern seni anamorfisme berkembang menjadi street art ataupun landscape art dimana publik bisa menikmati dengan bebas dengan mencari-cari vantage point dari gambar tersebut. Biasanya karya tersebut didokumentasi dalam bentuk foto dengan viewpoint yang benar sebagai tambahan pengalaman menikmati seni tersebut.

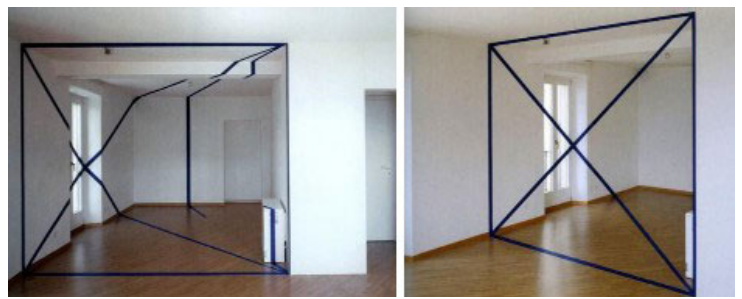

Gambar 15 Karya anamorfisme oleh Felice Varini

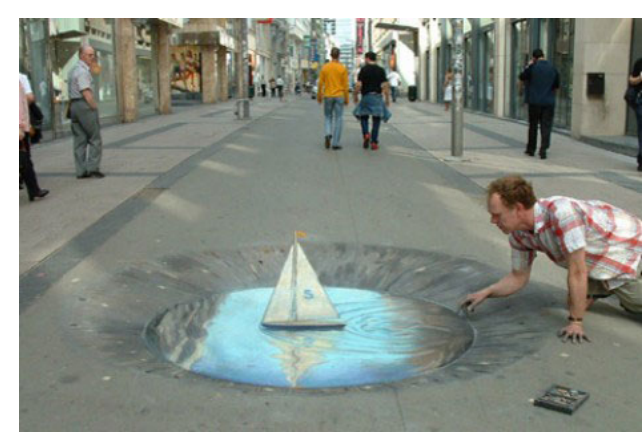

Gambar 16 Karya anomorfisme oleh Julian Beever

Forced Perspective adalah distorsi perspektif, di mana batas antara depan dan belakang menjadi tidak jelas sehingga memungkinkan manipulasi-manipulasi persepsi akan ukuran. Contoh ilusi optis ini banyak ditemukan dalam karya fotografi.

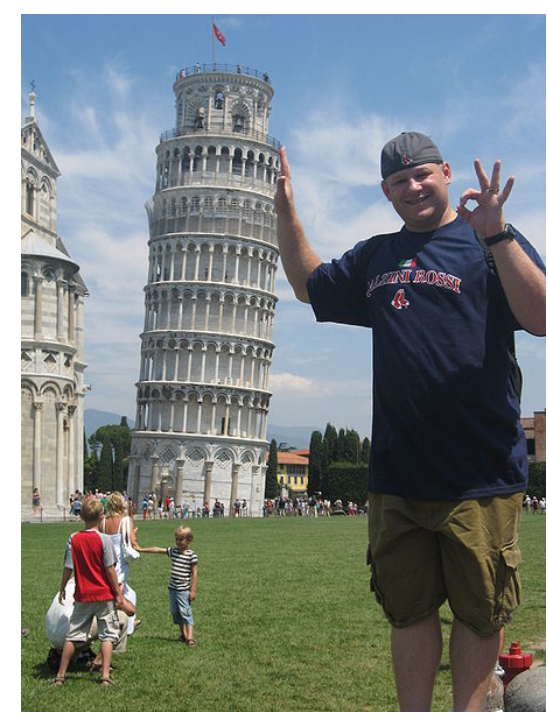

Gambar 17 Adegan foto yang sering diambil oleh para turis ketika mengujungi menara Pisa di Italia. Foto tersebut memperlihatkan seakan-akan pria tersebut menahan menara pisa tersebut. 
Fenomena Ames Room ditemukan oleh Adelbert Ames pada tahun 1934. Merupakan ruang di mana karena bentuknya, menciptakan ilusi optis terhadap ukuran objek di dalam ruang tersebut. Kunci dari ames room adalah bentuknya yang trapesium namun ketika dilihat melalui lubang pengamat menjadi ruang kotak biasa. Prinsip dari Ames Room banyak digunakan dalam industri film, seperti pada film Lord of The Ring, untuk mengambil adegan para hobbit dan sang penyihir dalam satu ruangan.

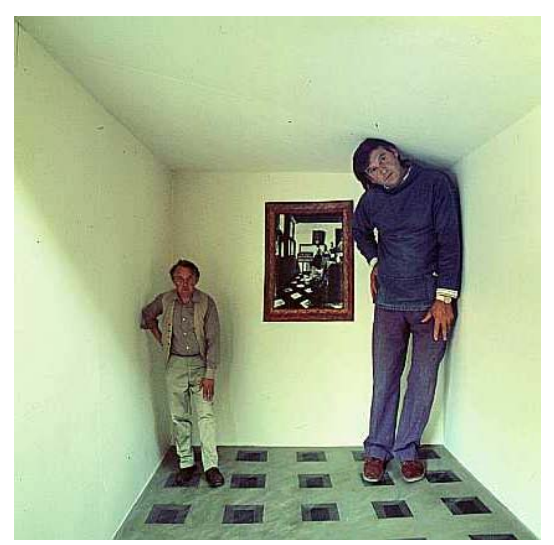

Gambar 18 Fenomena Ames Room

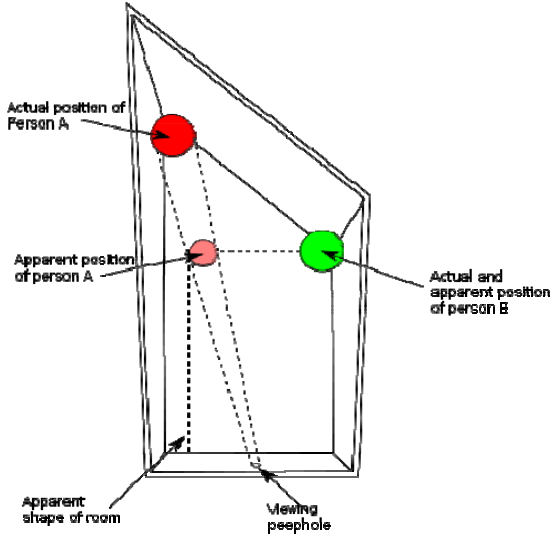

Gambar 19 Fenomena Ames Room

Fenomena Stereopsis adalah persepsi kedalaman yang didapat dikarenakan penglihatan binocular kita. Bahwa kita melihat menggunakan dua mata yang berbeda letaknya sehingga memiliki sudut pandang yang berbeda pula, namun informasi dari kedua mata kita tersebut kemudian disatukan dan memberi kita satu visual dengan persepsi bentuk tiga dimensi atau informasi kedalaman suatu objek. Dengan menggunakan prinsip ini lahirlah banyak bentuk karya 3 dimensi. Seperti karya-karya autostereogram, yaitu karya visual dua dimensi yang dapat memunculkan bentuk tiga dimensi setelah dilihat dengan teknik tertentu dan penciptaan film-film tiga dimensi, menggunakan kacamata khusus, yang akhir-akhir ini kembali marak digunakan.

\section{Paradox Illusion}

Merupakan ilusi optis di mana mata kita melihat sesuatu yang bertentangan dengan logika itu, sesuatu yang mustahil, mengakibatkkan pertentangan dalam menerjemahkan suatu input visual. Biasanya melibatkan interpretasi kita dalam menerjemahkan gambar dua dimensi sebagai gambar tiga dimensi. Ilusi ini telah diterjemahkan oleh para ilmuan dalam bentuk visual seperti blivet, penrose triangle, penrose stairs. Karya yang cukup terkenal yang menggunakan prinsip ini seperti karya Waterfall oleh M.C Escher.

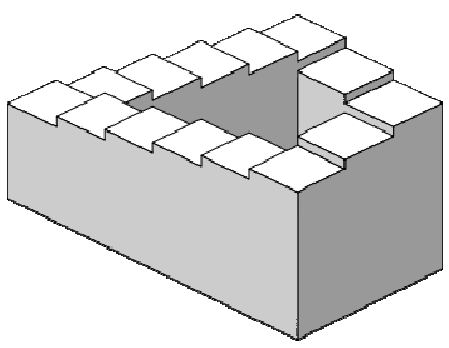

Gambar 20 Penrose Stair, merupakan tangga yang mustahil karena tiada berujung 


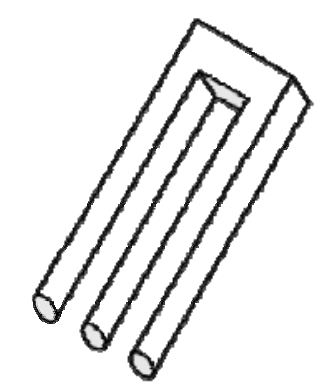

Gambar 21 Blivet, merupakan bentuk trisula dengan tiga silinder di ujungnya, namun hanya terlihat dua di ujung lainnya

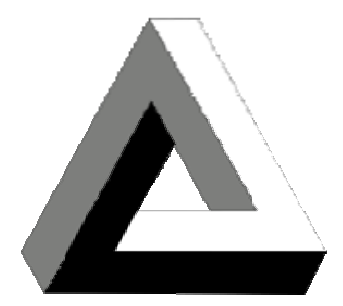

Gambar 22 Penrose Triangle, merupakan struktur segitiga dengan twist yang musathil di sudut-sudutnya

Paradox Illusion juga menjadi ide dalam pembuatan objek-objek seni tiga dimensi. Seperti pada karya Magic Tap, memperlihatkan keran air yang melayang di udara tapi mengucurkan air terus menerus, bentuk tiga dimensi dari Penrose triangle dan lain-lain.

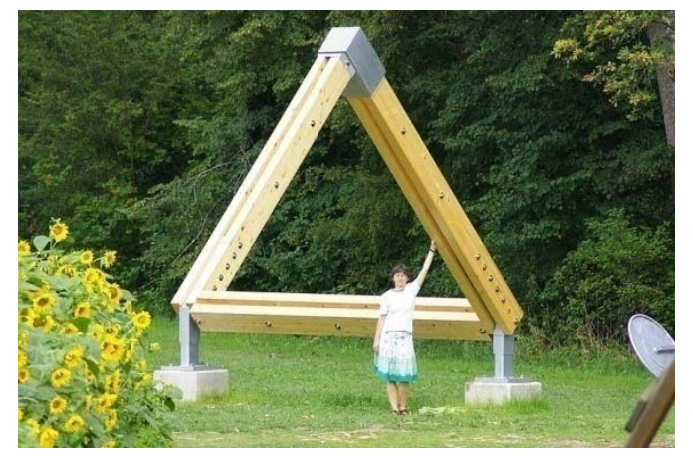

Gambar 23 Penrose triangle

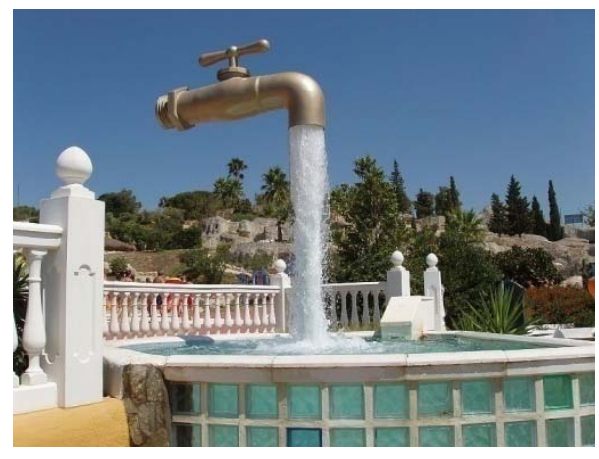

Gambar 24 Magic tap

\section{Fiction}

Contoh konkret dari fiction adalah mirage, yaitu suatu fenomena optis yang terjadi akibat pembelokan cahaya menghasilkan pantulan seperti cermin pada objek-objek yang jauh ataupun langit. Contoh paling mudah adalah ketika kita melihat jalan raya dalam kondisi cuaca panas yang mengeluarkan bayang-bayang seperti air atau Fatamorgana yang sering terjadi di gurun pasir. 


\section{SIMPULAN}

Dari pembahasan di atas, maka diketahui berbagai jenis ilusi optis, bagaimana cara kerjanya dan prinsip-prinsip apa saja yang mendasari untuk terjadinya suatu ilusi optis tersebut. Semuanya itu tentu tidak cukup hanya dengan membaca dan mencoba mengerti, tapi diperlukan percobaanpercobaan yang terus menerus untuk mencapai hasil yang sempurna. Kepekaan visual dan perhitungan matematika yang akurat adalah salah satu kunci penting dalam penciptaan ilusi optis. Untuk itu, disarankan pembelajaran materi-materi tambahan sebagai pendukung penulisan ini seperti teori dasar persepsi visual dan ilmu matematika terapan. Namun dengan mengetahui elemen-elemen dasar dari fenomena ilusi optis, diharapakan pemahaman kita terhadap ilusi optis akan lebih terbuka dan menjadikan kita lebih bisa mengapresiasikan karya ilusi optis. Dengan tulisan ini diharapakan menjadi landasan awal dalam eksplorasi dunia ilusi optis.

\section{DAFTAR PUSTAKA}

Anrtson, A. E. C. (2007). Graphic Design Basics. Stamford, Connecticut: Thomson Wadshorth.

Goldstein, E., \& Bruce, C. (2007). Sensation and Perception. Stamford, Connecticut: Thomson Wadshorth.

Rookes, P., \& Willson, J. C. (2000). Perception, Theory, Development and Organization. London: Routledge.

Solso, R. L. (2003). The Psychology of Art and the Evolution of Conscious Brain. Cambridge, Massachusetts: The MIT Press.

Vega, W. (2006). Ilusi Mata, Tipuan Penglihatan. Jakarta: Megindo Tunggal Sejahtera. 